\title{
Acquisition of the nongeneric use of the definite article "the" by Egyptian EFL learners
}

\section{Dr. Aly Shokry Aly Abdel Kader \\ (Lecturer of TEFL, Faculty of Education, Menoufia University)}

Abstract: This study investigates the acquisition of the nongeneric use of the definite article "the" by Egyptian EFL learners over a period of eight months. Sixty students at two levels of language proficiency (low, high) from the English Department, Faculty of Education, Menoufia University, participated in the study. The theoretical approach adopted was Liu and Gleason's (2002) model of classification, which classifies the nongeneric use of the into four major types: textual, structural, situation, and cultural. The study aims to determine whether these uses present different levels of difficulty for Egyptian EFL learners, and whether or not they are acquired at the same time. Besides, the study seeks to determine the extent to which students' English proficiency level (low, high) affects their acquisition of these uses.

Data were collected by administering a 46-item test twice to the participants, with a period of eight months between the first and second administrations. The test required the participants to complete each question sentence by choosing either the, $a(n)$ or $\emptyset$. The findings indicate that the four nongeneric uses of the present different levels of difficulty for Egyptian EFL university learners and do not appear to be acquired at the same time. On both the first and second administrations of the test, both structural and textual uses proved to be the most difficult for the two levels of proficiency followed in order by situation use and cultural use. Moreover, there was a significant improvement in the students'

مجلة كلية التربية- جامعة عين شمس 15 () العدد الواحد والأربعون (الجزء الثاني) 2017 
Acquisition of the nongeneric use of the definite article "the" by Egyptian EFL learners

command of the four nongeneric uses of the as the level of proficiency increases. Finally, after a period of eight months, students of the low-level group noticeably improved their level of command of the nongeneric uses of the, while students of the high-level group failed to do so.

Keywords: EFL, article acquisition, definite article, nongeneric uses, hierarchy of difficulty, Egyptian learners 


\title{
اكتساب متعلمي اللغة الإنجليزية المصريين للاستخدام
}

\section{لأداة التعريف "أل"”'nongeneric"الخاص الاص}

\author{
د. على شكري على عبد القادر
}

(مدرس مناهج وطرق تدريس اللغة الإنجليزية، كلية التربية، جامعة المنوفية)

تبحث الدراسة الحالية في اكتساب متعلمي اللغة الإنجليزية للاستخدام الخاص "nongeneric" لأداة التعريف "أل" على مدى ثمانية أشهر • وشارك في الدراسة ستون طالبا بمستويين من الكفاءة اللغوية (منخفضة وعالية) من قسم اللغة الإنجليزية، كلية التربية، جامعة المنوفية. وتبنت الدراسة تصنيف ليو وجليسون(2002) الذي يصنف هذا الاستخدام إلى أربعة أنواع رئيسية هي:

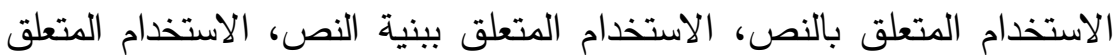

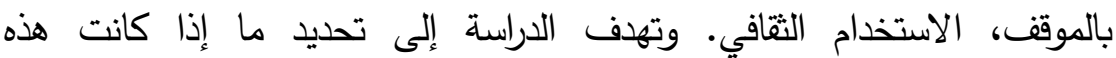
الاستخدامات تمثل مستويات مختلفة من الصعوبة لدى المتعلمين المصريين

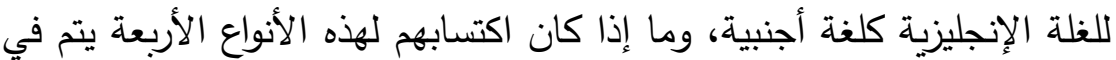
الوقت نفسه أم لا. إلى جانب ذلك، تسعى الدراسة إلى تحديد مدى تأثير مستوي الكفاءة اللغوية (منخفضة وعالية) لدى الطلاب على اكتسابهم لهذه

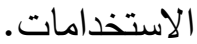

وجمعت البيانات عن طريق تطبيق اختبار مكون من 46 سؤال على عينة

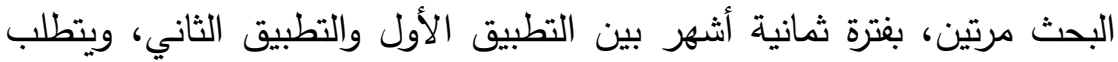

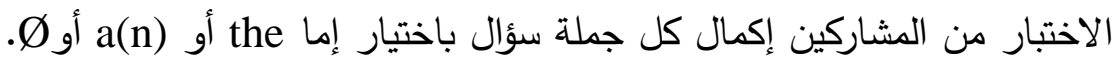

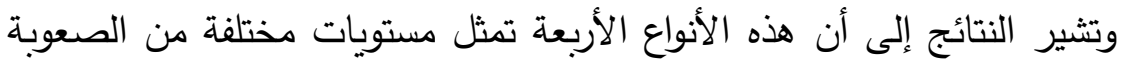
بالنسبة للمتعلمين، وأن اكتسابهم لها يحدث في مراحل مختلفة. فقد أظهرت نتائج الأن

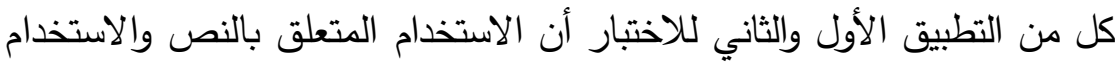

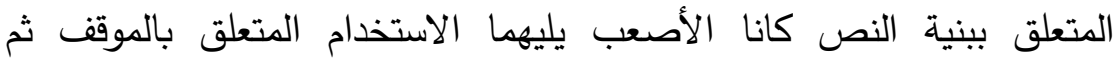


Acquisition of the nongeneric use of the definite article "the" by Egyptian EFL learners

الاستخدام الثقافي وذلك بالنسبة للطلاب ذوي المستوى المنخفض أو المستوى

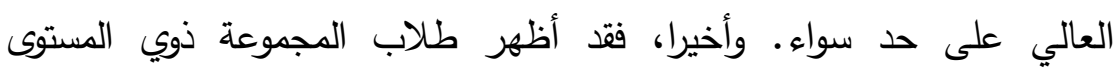
المنخفض، بعد فترة من ثمانية أشهر، تحسن ملحوظ في مستوى تمكنهم من فن

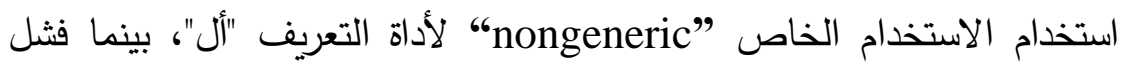
طلاب المجموعة ذوي المستوى العالي في تحقيق ذلك. الكلمات الادالة: اللغة الإنجليزية كلغة أجنبية، اكتساب أداة التعريف "أل"،

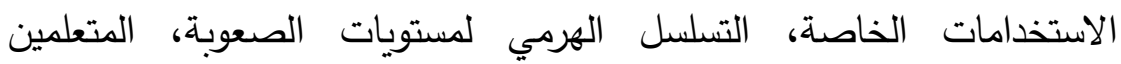
المصرين 


\title{
Acquisition of the nongeneric use of the definite article "the" by Egyptian EFL learners
}

\author{
Dr. Aly Shokry Aly Abdel Kader \\ (Lecturer of TEFL, Faculty of Education, Menoufia \\ University)
}

\section{Introduction}

The English article system comprises the definite article the, the indefinite article $a / a n$ and the zero/null article $\varnothing$. These articles affect the information structure of the text. They often act as cohesive elements and have the function of unifying the text. When an article is missing or the wrong article is used, this can be quite disruptive for the reader/listener and may lead to wrong comprehension of the message conveyed.

Articles are among the most frequently used function words in English, which should provide learners of English with increased levels of accuracy of their various uses. Nevertheless, many researchers (e.g., Garcia Mayo, 2008; Master, 1990; McEnery, Xiao, \& Tono, 2006; Mizuno, 1999) have reported that the English article system is one of the most difficult linguistic features for ESL/EFL learners due to its complex usage. Master (2002, pp. 331-333) attributes part of this complexity to the fact that the English article system stacks multiple functions (definiteness, countability, and number) onto a single morpheme, which results in a considerable burden for the learner. Moreover, the decisions affecting the choice of an article within these multiple functions are based on a complex mix of factors - that is, whether or not a form of a noun has a specific referent and whether or not it is identifiable to the reader/listener. Because of this great complexity, most nonnative speakers of

مجلة كلية التربية- جامعة عين شمس 19 () العدد الواحد والأربعون (الجزء الثاني) 2017 


\section{Acquisition of the nongeneric use of the definite article "the" by Egyptian EFL learners}

English do not completely master the article system until a rather late stage during the course of language acquisition and, as Garcia Mayo (2008, p. 551) states, sometimes never reach native-like levels of proficiency.

Given the complex usage of the English article system and the difficulty involved in its analysis, linguists have long been interested in developing models for analyzing and classifying its uses. One of the early systematic approaches to the analysis of these uses has been proposed by Bickerton (1981) who maintained that the use of the article is governed by the semantic function of the noun phrase in discourse. This semantic function, he argued, depends on whether or not the noun has a specific referent and whether or not the noun is assumed to be known to the hearer.

Based on Bickerton's model, Huebner (1983, 1985) developed his semantic wheel model, which has been widely used in English article acquisition studies. In Huebner's model, nouns are classified as $+/-$ specific referent $[ \pm \mathrm{SR}]$ and $+/-$ assumed known to the hearer $[ \pm \mathrm{HK}]$. In terms of these two binary features, nouns are classified under four basic semantic types that determine the use of the article. The first type, nouns classified as $[-\mathrm{SR},+\mathrm{HK}]$, comprises generic nouns. These nouns are marked with $a / a n$, the, or $\emptyset$ if the noun is plural. The second type, nouns classified as $[+\mathrm{SR},+\mathrm{HK}]$, includes unique referents or conventionally assumed unique referents; that is, referents that are physically present, referents previously mentioned in the discourse, and specific referents assumed to be known to the hearer. This type includes most of the uses of the. The third type, nouns classified as $[+\mathrm{SR},-\mathrm{HK}]$, includes referential indefinite nouns; that is, first mention nouns as well as nouns that follow existential 'have' and are assumed to be unknown

مجلة كلية التربية- جامعة عين شمس 20 () العدد الواحد والأربعون (الجزء الثاني) 2017 
to the hearer. These nouns are marked with $a / a n$ or $\emptyset$ if the noun is plural. The fourth type, nouns classified as [-SR, $\mathrm{HK}]$, includes non-referential nouns that are marked with a/an or $\emptyset$.

\section{Theoretical background to uses of the}

The various uses of the definite article are usually classified by Grammarians (Celce-Murcia \& LarsenFreeman, 1999; Hawkins, 1978; Quirk, Greenbaum, Leech, $\&$ Svartvik, 1985) under two main categories, generic and nongeneric. In its generic use, the definite article is usually used with a singular count noun to indicate a class of entities (e.g., a species, a race, or people of a nation), as in The German is very athletic. In this case, it can usually be replaced with the indefinite article $a(n)$. However, the may also be used with plural nouns, as in The Germans are very athletic, where it can be replaced by the zero article $\varnothing$ (Celce-Murcia \& Larsen-Freeman, 1999). The generic use of the, as Parrish (1987) and Tarone and Parrish (1988) state, has been found to be very rare, except in the scientific register.

The nongeneric use of the, on the other hand, is much wider and more frequent than its generic use as it includes all its other uses. Unlike the generic use, it cannot be replaced by either the indefinite article or the zero article. As Liu and Gleason (2002, p. 6) indicate, the nongeneric use of the is much more complex and hence more problematic for ESL/EFL learners. Therefore, the present study is an attempt to investigate the acquisition of the nongeneric uses of the English definite article by Egyptian EFL university students.

Different classifications of the nongeneric the have been proposed. In an attempt to classify the various nongeneric uses of the, Hawkins (1978) developed a theory known as the Location Theory. According to this theory, the definite article

مجلة كلية التربية- جامعة عين شمس 21 () العدد الواحد والأربعون (الجزء الثاني) 2017 
Acquisition of the nongeneric use of the definite article "the" by Egyptian EFL learners

functions as an instruction for the reader/listener to locate the referent by using provided or assumed known cultural, situational, or textual information. Hawkins (1978, pp. 106149) identified eight nongeneric uses of the, which are illustrated with the corresponding examples in Table 1 below:

Table 1

Hawkins' Eight Types of Nongeneric Use of "the"

1. Anaphoric use: use of the when something is mentioned a second time (e.g., I bought a new couch. The couch is brown.)

2. Visible situation use: use of the with a noun mentioned the first time to refer to something that both the speaker and the listener can see (e.g., Excuse me, would you pass me the salt, please?)

3. Immediate situation use: this use is very similar to \#3, the only difference being that the thing referred to may not be visible. (E.g., Don't go in there. The walls were just painted.)

4. Larger situation use relying on specific knowledge: use of the with a first-mention noun because it is known in the community (e.g., the church, the pub)

5. Associative anaphoric use: this use is similar to \#1, the only difference is that the is used with a noun that is related to a previously mentioned noun, rather than being the same noun. (E.g., I got into the car, but the engine wouldn't start.)

6. Larger situation use relying on general knowledge: use of the with something that one can assume people from a country or around the world should know (e.g., the moon, the White House)

مجلة كلية التربية- جامعة عين شمس 22 () العدد الواحد والأربعون (الجزء الثانى) 2017 
7. Unfamiliar use in noun phrases with explanatory modifiers: use of the with a first-mention noun that has an explanatory or identifying modifier in the form of a clause, prepositional phrase, or noun (e.g., The movies that are shown here now are all rated $R$; The boy in the blue shirt is my cousin; I hate the name Algernon.)

8. Unfamiliar use in noun phrases with non-explanatory modifiers: this use is similar to \#3, the only difference being that the modifier does not provide explanatory information. (E.g., My brother and I share the same secrets.)

A more recent classification system of the nongeneric uses of the definite article "the," which was based on Hawkins's (1978) Location Theory, was proposed by Liu and Gleason (2002). As it is clear from table 2 below, Liu and Gleason combined some of Hawkins' eight types and classified the nongeneric uses of the into four major types: textual, structural, situation, and cultural.

Table 2

Liu and Gleason's Four Types of Nongeneric Use of "the"

1. Textual use: the is used with a noun that has been previously mentioned or that is related to a noun that has been previously mentioned. This type includes both anaphoric and associative anaphoric use of Hawkins' classification. (E.g., I got into the car, but the engine wouldn't start.)

2. Structural use: this type includes the use of the with a firstmention noun that has an explanatory modifier in the form of a clause, prepositional phrase, or noun. (E.g., The beef that is produced in the United Kingdom is not allowed to be exported to other European nations.)

3. Situation use: the is used when the referent of a firstmention noun can be sensed directly or indirectly by the interlocutors involved, or the referent is known to members of the local community. This type includes

مجلة كلية التربية- جامعة عين شمس 23 () العدد الواحد والأربعون (الجزء الثاني) 2017 


\section{Acquisition of the nongeneric use of the definite article "the" by Egyptian EFL learners}

visible situation use, immediate situation use, and larger situation use relying on specific knowledge of Hawkins' classification. (E.g., Excuse me, would you pass me the salt, please?)

4. Cultural use: the is used with a noun that is a unique and well-known referent in the speech community. As Liu and Gleason $(2002,8)$ illustrate, this use of the is determined, to a large extent, by conventional practice. (E.g., She was very kind. She gave me the best advice I could get as to the purchase of a house.)

\section{Review of Literature}

Many studies have been carried out investigating the acquisition of English articles by ESL learners whose native languages do not use articles: Chinese (Robertson, 2000), Chinese and Malay (Wong \& Quek, 2007), Japanese (Butler, 2002; Mizuno, 1999; Takahashi, 1997), Persian (Ansarin 2004), and Turkish (Dikilitas \& Altay, 2011). The findings of these studies revealed that ESL learners have difficulty acquiring English articles.

One such study was conducted by Liu and Gleason (2002) who investigated the acquisition of the definite article the by ESL students with different levels of proficiency. In this study, Liu and Gleason presented their classification of the nongeneric uses of the English definite article under four major categories: cultural, situation, structural, and textual. The researchers aimed to determine whether these four uses present the same learning difficulty for ESL students and whether they are acquired at the same time. Although their participants were from 18 different language backgrounds, the majority of them were speakers of Chinese, Korean, and Japanese-languages that do not use articles. The participants were presented with 91 sentences with 60

مجلة كلية التربية- جامعة عين شمس 24 () العدد الواحد والأربعون (الجزء الثاني) 2017 
deleted obligatory uses of the and were asked to read the sentences and insert the where they deemed necessary. The results clearly indicated a hierarchy of difficulty in the acquisition of the four types with cultural use being the most difficult, followed in order by textual use, structural use, and situation use. In addition, they found that the number of missed uses of the, in all four types, decreased as the subjects' proficiency increased, with the most significant decrease occurring at the intermediate level. The most significant improvements were in the structural and textual use of the, continuing through the advanced level. On the other hand, the improvements in both situation and cultural uses were more slowly after the intermediate level.

A number of subsequent studies replicated Liu and Gleason's study with the goal of investigating whether their proposed hierarchy of difficulty can be validated with different samples of participants. In three of these studies, the participants were native speakers of languages that that do not use articles. Ansarin (2004) investigated the acquisition of the four nongeneric uses of the by native speakers of Persian, Wong and Quek (2007) examined the acquisition of these uses by native speakers of Mandarin Chinese and Malay, and Dikilitas and Altay (2011) investigated their acquisition by native speakers of Turkish. The results of these studies independently confirmed the difficulty hierarchy proposed by Liu and Gleason. According to the findings of these studies, cultural use turned out to be the most difficult, while situation use presented the least difficulty, and both structural and the textual uses occupied an intermediate position between situation and cultural uses.

Another two studies replicated Liu and Gleason's study using learners whose native languages has article systems. The first was conducted by García Mayo (2008) who investigated the acquisition of the four nongeneric uses of the

مجلة كلية التربية- جامعة عين شمس 25 () العدد الواحد والأربعون (الجزء الثاني) 2017 


\section{Acquisition of the nongeneric use of the definite article "the" by Egyptian EFL learners}

by L1 Spanish learners with different levels of proficiency. Results of the study supported Liu and Gleason's hierarchy of difficulty in the acquisition of the nongeneric uses of the, with cultural being the most difficult followed in order by textual use, structural use and situation use. In addition, learners' underuse of obligatory the decreased significantly from elementary to low-intermediate level; however, this did not hold for the transition between the low intermediate and advanced levels.

The second study was conducted by Alenizi (2013) using native speakers of Arabic. The participants were Saudi EFL university learners with low intermediate, intermediate, and advanced levels of language proficiency. The findings of the study showed that the four nongeneric uses of the definite article represent different levels of difficulty for the participants. However, unlike the other studies that replicated Liu and Gleason's study, Alenizi's study revealed a different hierarchy of difficulty. Across the three levels of language proficiency, textual use turned out to be the most difficult, followed in order by both structural and cultural uses, while situation use was the least difficult.

\section{The Problem}

The acquisition of English articles by ESL learners whose native languages do not use articles has been researched extensively; on the other hand, few studies have investigated the acquisition of articles by learners whose mother tongue does have an article system such as Arabic. A limited number of these studies were specifically delimited to the acquisition of the nongeneric use of the English definite article the. In addition, after examining the written work of students of the English Department at the Faculty of Education, Menoufia University, the researcher found out that

مجلة كلية التربية- جامعة عين شمس 26 () العدد الواحد والأربعون (الجزء الثان) 2017 
they still have trouble using the correct article, despite their early exposure to and frequent use of English articles.

The purpose of this study is, therefore, to investigate Egyptian EFL university students' acquisition of the nongeneric uses (textual, structural, situation, and cultural) of the English definite article the-based on the classification proposed by Liu and Gleason (2002). The study seeks to find out whether these four nongeneric uses of the present different levels of difficulty for the students; that is, whether these uses are acquired in a certain sequence. In addition, the study aims to determine the extent to which students' English proficiency level (low, high) affects their acquisition of these nongeneric uses of the.

To achieve the above objectives, this study sought to answer the following research questions:

1. Do the four nongeneric uses of the determined by Liu and Gleason (2002) (textual, structural, situation, and cultural) present different levels of difficulty for Egyptian EFL university students? If so, in what order do they acquire these uses?

2. To what extent does students' English proficiency level (low, high) affect their acquisition of these four nongeneric uses of the?

\section{Methodology}

\section{Participants}

Sixty EFL university students participated in the present study. They were selected from the 137 students who were enrolled in the $2^{\text {nd }}$ year, English Section (Basic Education), Faculty of Education, Menoufia University. Two EFL proficiency-level groups (thirty each) were formed through the following procedure. At first, all students of the $2^{\text {nd }}$ year were administered the grammar and reading comprehension sections of a form of the English Placement Test of the

مجلة كلية التربية- جامعة عين شمس 27 () العدد الواحد والأربعون (الجزء الثاني) 2017 


\section{Acquisition of the nongeneric use of the definite article "the" by Egyptian EFL learners}

University of Michigan. Then, they were rank ordered according to their scores on the test. Finally, the top 30 students were regarded as the more proficient learners and were assigned to the high-level group, and the bottom 30 students were regarded as the less proficient learners and were assigned to the low-level group.

To determine whether the two groups formed by this procedure actually differed in their EFL proficiency level, an independent samples t-test was conducted on the scores of the two groups on the test. As Table 3 shows, there was a significant difference between two groups' mean scores on the test.

Table 3

Results of an Independent Samples t-Test on the Two Groups' Mean Scores on the Grammar and Reading Comprehension Test

\begin{tabular}{|c|c|c|c|}
\hline & & t-test for Equality & fMeans \\
\hline Group & $S D$ & $\begin{array}{lcc}t & d f & M \\
& & \text { Difference }\end{array}$ & $\begin{array}{l}\text { Std. } \\
E D\end{array}$ \\
\hline
\end{tabular}

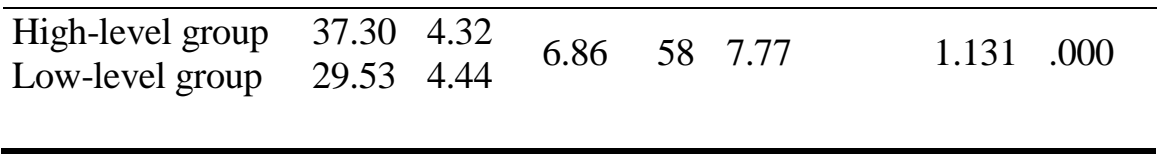

\section{Instruments}

The instruments of the present study were two tests, a test of grammar and reading comprehension and a test of the English article system. The Grammar and Reading Comprehension Test consisted of the grammar and the reading comprehension sections of a form of the English Placement Test of the University of Michigan. The grammar section consisted of thirty multiple-choice completion items. The task of the participants was to read a dialogue with a

مجلة كلية التربية- جامعة عين شمس 28 () العدد الواحد والأربعون (الجزء الثاني) 2017 
missing word/phrase and to choose from the four choices that follow the one that best completes it. The reading comprehension section was composed of twenty multiplechoice items. Each item required the participants to read a sentence and answer a question about it through choosing the best answer from the four choices that follow. The proficiency level of the participants was determined based on their performance on this test.

The Article Test consisted of 46 multiple-choice items that were selected and adapted from the 60 -item test used by Takahashi (1997) in his study of Japanese learners' acquisition of the English article system (see Appendix A). The test required the participants to complete each question sentence by choosing either the, $a(n)$ or $\varnothing$. In 25 of the sentences, there were 25 deleted obligatory nongeneric uses of the. These items were used to measure students' use of the four nongeneric uses of the; that is, the textual use (4 items), structural use ( 8 items), situation use ( 8 items), and cultural use (5 items). The remaining 21 items of the test were included as distracters and were randomly inserted among the experimental test items. Fifteen of these items required the participants to choose $a(n)$ and six required them to choose $\varnothing$.

\section{A. Test validity}

To ascertain the validity of the test, the original 60 -item test used by Takahashi was presented to three native speakers of English and five English language instructors at faculties of education and faculties of arts for completion and revision. Based on their responses, 14 items were excluded because of their ambiguity. The remaining 46 items were considered clear and appropriate for testing students' use of the.

\section{B. Test reliability}

Test reliability was computed using the Split-Half method using the scores of the low-level group on the first

مجلة كلية التربية- جامعة عين شمس 29 () العدد الواحد والأربعون (الجزء الثاني) 2017 


\section{Acquisition of the nongeneric use of the definite article "the" by Egyptian EFL learners}

administration of the Article Test. This statistical procedure yielded a Spearman-Brown Coefficient of .812 and a Guttman Split-Half Coefficient of .811 for the test. Therefore, the test was considered reliable in measuring the participants' use of the nongeneric uses of the definite article.

\section{Procedure}

\section{A. Administration of the Tests}

At first, the Grammar and Reading Comprehension Test was administered to all students (137 students) who were enrolled in the second year of study at the English Department. The students were given 40 minutes to answer the test. Based on the students' performance on this test, the two proficiency-level groups of the study were formed using the procedure described before. At the beginning of the second semester, the Article Test was first administered to the two groups in one session. After a period of about eight months, the same test was administered again to the two groups in one session. In both occasions, the participants were told to choose $\varnothing$ when neither the nor $a(n)$ was necessary. Even though there was no time limit for the test, the participants took approximately 15 to 25 minutes to complete it.

\section{B. Scoring the Tests}

The Grammar and Reading Comprehension Test was scored so that each choice was counted either correct or incorrect. Therefore, each subject was given a score out of fifty on the test. In scoring the Article Test, each participant was awarded one point for each correct choice of the. Each participant received four scores on the test, corresponding to each type of use: a textual, structural, situation, and cultural use score. These scores were converted to percentage scores

مجلة كلية التربية- جامعة عين شمس 30 () العدد الواحد والأربعون (الجزء الثاني) 2017 
to avoid biases related to the unequal number of items allocated to each of the four types on the test. The percentage score was calculated by dividing the number of correct choices made by the participant on each type by the total number of items allocated to this type on the test.

\section{Data Analysis}

After tabulating the results of the participants' performance on the first and second administrations of the Article Test, the collected data were analyzed using the SPSS program for statistical procedures (Version 16). At first, descriptive statistics of the correct uses of the in each of the four types of use for each proficiency-level group were calculated. Then, two separate two-way ANOVAs were conducted on the participants' scores across the four types of use for the two proficiency levels, on the first and second administrations of the Article Test. In these analyses, the type of use (textual, structural, situation, cultural) and the level of proficiency (low, high) were treated as independent variables, and the participants' correct uses of the, as measured by their scores on the test, as a dependent variable. These analyses were conducted to examine the effects of the type of use and the level of proficiency on students' correct use of the on the first and second administrations of the test. Following this, pairwise t-test comparisons were used to determine where the significant difference(s) lay among all possible type of use pairs, and independent samples t-tests were used to determine where the significant differences between the low-level and the high-level groups lay. For all statistical analyses, a .05 criterion of statistical significance was employed. The following section presents the results of these statistical analyses.

\section{Findings and Discussion}

\section{Correct Use of Nongeneric the}

The collected data were first analyzed to compute descriptive statistics for the participants' performance on

مجلة كلية التربية- جامعة عين شمس 31 () العدد الواحد والأربعون (الجزء الثاني) 2017 


\section{Acquisition of the nongeneric use of the definite article "the" by Egyptian EFL learners}

both the first and second (eight months later) administrations of the Article Test. Descriptive statistics per type of use and level of proficiency for the first and second administrations are shown in Table 4 and Table 5, respectively.

As can be seen in Table 4, the low-level group achieved the highest mean score in cultural use (87.33) followed by situation use

Table 4

Descriptive Statistics for Each Type of Use and Level of Proficiency on the First Administration of the Test

\begin{tabular}{lllllll}
\hline \multirow{2}{*}{ Group } & Descriptive & \multicolumn{5}{c}{ Type of Use } \\
& Statistics & Textual & Structural & Situation & Cultural & Total \\
\cline { 2 - 7 } Low $^{*}$ & $M$ & 66.67 & 61.25 & 75.63 & 87.33 & 72.72 \\
& $S D$ & 17.78 & 19.52 & 16.90 & 19.99 & 20.86 \\
High $^{*}$ & $M$ & 82.50 & 87.50 & 89.16 & 97.33 & 89.13 \\
& $S D$ & 18.74 & 12.28 & 12.60 & 6.91 & 14.19 \\
\multirow{2}{*}{ Total } & $M$ & 74.58 & 74.38 & 82.40 & 92.33 & 80.92 \\
& $S D$ & 19.79 & 20.89 & 16.28 & 15.66 & 19.61 \\
\hline
\end{tabular}

${ }^{*} \mathrm{n}=30$

(75.63), textual use (66.67), and structural use (61.25). This table also shows that the high-level group achieved the highest mean score in cultural use (97.33) followed by situation use (89.16). Unlike the low-level group, the mean score of the high-level group in structural use (87.50) was higher than its mean score in textual use (82.50).

This shows that, at the time of the first administration of the test, both groups performed best in cultural use followed by situation use. However, they differed in their performance in textual use and structural use, even though the difference between the mean scores of each group in textual and structural uses was small. While structural use appeared to

مجلة كلية التربية- جامعة عين شمس 32 () العدد الواحد والأربعون (الجزء الثاني) 2017 
be the most difficult for the low-level group, textual use seemed to be the most difficult for the high-level group.

Table 5

Descriptive Statistics for each Type of Use and Level of Proficiency on the Second Administration of the Test

\begin{tabular}{lllllll}
\hline \multirow{2}{*}{ Group } & \multicolumn{2}{l}{ Descriptive } & \multicolumn{5}{c}{ Type of Use } \\
& Statistics & Textual & Structural & Situation Cultural & Total \\
\hline \multirow{2}{*}{ Low $^{*}$} & $M$ & 78.33 & 79.58 & 84.83 & 97.33 & 85.02 \\
& $S D$ & 15.72 & 15.22 & 10.72 & 6.91 & 14.60 \\
\multirow{2}{*}{ High $^{*}$} & $M$ & 84.17 & 82.50 & 85.83 & 100.00 & 88.13 \\
& $S D$ & 13.90 & 11.18 & 9.70 & .00 & 12.22 \\
\multirow{2}{*}{ Total } & $M$ & 81.25 & 81.04 & 85.33 & 98.67 & 86.57 \\
& $S D$ & 15.00 & 13.32 & 10.15 & 5.03 & 13.53 \\
\hline
\end{tabular}

${ }^{*} \mathrm{n}=30$

At the time of the second administration of the test, as Table 5 indicates, the low-level group achieved the highest mean score in cultural use (97.33) followed by situation use (84.83), structural use (79.58), and textual use (78.33). The high-level group, like the low-level group, achieved the highest mean score in cultural use (100.00) followed by situation use (85.83). In contrast to the low-level group, the high-level group achieved a higher mean score in textual use (84.17) than in structural use (82.50). Once again, there was a small difference between the mean scores of each group in textual and structural uses.

To sum up, on both the first and second administrations of the Article Test, the two groups performed best in cultural use followed by situation use. However, there were variations in their performance in textual and structural types of use, even though the difference between each group's mean scores in textual and structural uses was small.

Interestingly, the performance of the low-level group on the first administration of the test was similar to that of the high-level group on the second administration. Both groups

مجلة كلية التربية- جامعة عين شمس 33 () العدد الواحد والأربعون (الجزء الثاني) 2017 


\section{Acquisition of the nongeneric use of the definite article "the" by Egyptian EFL learners}

performed best in cultural use followed in order by situation, textual, and structural uses. Moreover, the low-level group performed on the second administration of the test in a manner similar to that of the high-level group on the first administration; they both performed best in cultural use followed in order by situation, structural, and textual uses.

\section{Effects of Type of Use and Proficiency Level}

To determine the effects of the four nongeneric uses of the and students' English proficiency level on their accuracy of use of the, 2 separate two-way ANOVAs were conducted on the participants' scores across the four types of use for the two proficiency levels on the first and second administrations of the Article Test. The results of these analyses are presented in Table 6 and Table 8.

\section{A. Order of difficulty of the four nongeneric uses of the}

With regard to the effect of type of use of the, the ANOVA results, presented in Table 6 , indicate that it had a statistically significant effect, $F(3,232)=16.49, p<.001$, with an effect size (partial $\eta^{2}$ ) of .18 . This result implies that, on the first administration of the test, $18 \%$ of the variance in the dependent variable was accounted for by the type of use.

Table 6

ANOVA Results for the Two Proficiency Levels across the Four Types of Use on the First Administration of the Test

\begin{tabular}{llllll}
\hline Source & $S S$ & $d f$ & $M S$ & $F$ & Partial $\eta^{2}$ \\
\hline Type of use & 12926.70 & 3 & 4308.90 & $16.49^{*}$ & .18 \\
Proficiency level & 16145.80 & 1 & 16145.80 & $61.77^{*}$ & .21 \\
Type of use & 2197.82 & 3 & 732.61 & 2.48 & .03 \\
x Proficiency level & & & & & \\
Error & 60638.51 & 232 & 261.37 & & \\
Total & 1663553.25 & 240 & & & \\
\hline
\end{tabular}

مجلة كلية التربية- جامعة عين شمس 34 () العدد الواحد والأربعون (الجزء الثاني) 2017 
${ }^{*} p<0.05$

Since the ANOVA analysis revealed a significant effect for the type of use of the, pairwise t-test comparisons were conducted to find out the pair(s) that was/were significantly different, using the total scores of the two groups in each type of use. The results reported in Table 7 show significant differences between all pairs except for the structural vs textual pair.

Table 7

Results of Pairwise t-tests across the Four Types of Use on the First Administration of the Test

\begin{tabular}{|c|c|c|c|c|}
\hline Pair & $M$ Difference & Std. ED & $d f$ & $t$ \\
\hline Structural $^{\mathrm{a}}$ vs situation ${ }^{\mathrm{b}}$ & -8.03 & 3.42 & 118 & $-2.35^{*}$ \\
\hline Structural vs textual $^{c}$ & -.21 & 3.72 & 118 & -.056 \\
\hline Structural vs cultural $^{\mathrm{d}}$ & -17.96 & 3.37 & 118 & $-5.33^{*}$ \\
\hline Situation vs textual & 7.82 & 3.31 & 118 & $2.36^{*}$ \\
\hline Situation vs cultural & -9.93 & 2.92 & 118 & $-3.41^{*}$ \\
\hline Textual vs cultural & -17.75 & 3.26 & 118 & $-5.45^{*}$ \\
\hline
\end{tabular}

${ }^{\text {a Total } M \text { for Structural }=74.38(S D=20.89)}$

${ }^{\mathrm{b}}$ Total $M$ for Situation $=82.40(S D=16.28)$

${ }^{\mathrm{c}}$ Total $M$ for Textual $=74.58(S D=19.79)$

${ }^{\mathrm{d}}$ Total $M$ for Cultural $=92.33(S D=15.66)$ ${ }^{*} p<.05$

These results reveal that, on the first administration of the test, both the structural and textual uses of the were equally difficult for the participants in this study. They also reveal a hierarchy of difficulty among the four nongeneric uses of the, with both structural $(M=74.38)$ and textual $(M=$ 74.58) uses being the most difficult followed in order by situation use $(M=82.40)$ and cultural use $(M=92.33)$.

As in the case of the first administration of the test, the results obtained from the ANOVA conducted on the

مجلة كلية التربية- جامعة عين شمس 35 () العدد الواحد والأربعون (الجزء الثاني) 2017 


\section{Acquisition of the nongeneric use of the definite article "the" by Egyptian EFL learners}

participants' scores on the second administration of the test, as Table 8 shows, revealed a statistically significant effect for type of use, $F(3,232)=31.39, p<.001$, partial $\eta^{2}=.29$. This result indicates that type of use accounted for $29 \%$ of the variance in the dependent variable.

Table 8

ANOVA Results for the Two Proficiency Levels across the Four Types of Use on the Second Administration of the Test

\begin{tabular}{llllll}
\hline Source & $S S$ & $d f$ & $M S$ & $F$ & Partial $\eta^{2}$ \\
\hline Type of use & 12403.41 & 3 & 4134.47 & $31.39^{*}$ & .29 \\
Proficiency level & 578.15 & 1 & 578.15 & $4.39^{*}$ & .02 \\
Type of use & 181.54 & 3 & 60.51 & .46 & .006 \\
x Proficiency level & & & & & \\
Error & 30559.38 & 232 & 131.72 & & \\
Total & 1842491.25 & 240 & & & \\
$* p<0.05$ & & & &
\end{tabular}

Pairwise t-tests were, consequently, conducted between each possible pair to determine where the significant difference lay, using the two groups' total scores in each type of use. As Table 9 indicates, there were significant differences between all pairs except for the structural vs textual pair.

These results confirm those obtained from the first administration of the Article Test. Eight months after the first administration of the test, both the structural and textual uses of the proved to be of the same level of difficulty for the participants in the present study. Furthermore, these results display the same order of difficulty obtained from the first administration of the test among the four nongeneric uses of the, with both structural use $(M=81.04)$ and textual use $(M=$

مجلة كلية التربية- جامعة عين شمس 36 () العدد الواحد والأربعون (الجزء الثاني) 2017 
$81.25)$ being the most difficult followed in order by situation use $(M=85.33)$ and cultural use $(M=98.67)$.

Table 9

Results of Pairwise t-tests across the Four Types of Use on the Second Administration of the Test

\begin{tabular}{|c|c|c|c|c|}
\hline Pair & $M$ Difference & Std. ED & $d f$ & $t$ \\
\hline Structural $^{\mathrm{a}}$ vs situation ${ }^{\mathrm{b}}$ & -4.29 & 2.16 & 118 & $-1.99^{*}$ \\
\hline Structural vs textual ${ }^{c}$ & -.21 & 2.59 & 118 & -.08 \\
\hline Structural vs cultural $^{\mathrm{d}}$ & -17.63 & 1.84 & 118 & $-9.59^{*}$ \\
\hline Situation vs textual & 4.08 & 2.34 & 118 & $1.75^{*}$ \\
\hline Situation vs cultural & -13.33 & 1.46 & 118 & $-9.12^{*}$ \\
\hline Textual vs cultural & -17.42 & 2.04 & 118 & $-8.53^{*}$ \\
\hline
\end{tabular}

${ }^{\text {a Total }} M$ for Structural $=81.04(S D=13.32)$

${ }^{\mathrm{b}}$ Total $M$ for Situation $=85.33(S D=10.15)$

${ }^{\mathrm{c}}$ Total $M$ for Textual $=81.25(S D=15.00)$

${ }^{\mathrm{d}}$ Total $M$ for Cultural $=98.67(S D=5.03)$ ${ }^{*} p<.05$

With regard to the first question of the study, the results reveal that the four nongeneric uses of the represent different levels of difficulty for Egyptian EFL university students and do not appear to be acquired at the same time. Regardless of the proficiency level of the students, both structural and textual uses of the were the most difficult for Egyptian EFL university students and appeared to be acquired almost at the same time. On the contrary, cultural use proved to be the easiest followed in order by situation use. These findings, thus, only partly confirm the findings from other studies (e.g., Liu \& Gleason, 2002; Ansarin, 2004; Chan, 2005; Wong \& Quek, 2007; García Mayo, 2008; Dikilitas \& Altay, 2011) since they reveal that the four nongeneric uses of the represent different levels of difficulty for the learners and do not appear to be acquired at the same time. On the other hand, these findings do not confirm the difficulty hierarchy proposed by these

مجلة كلية التربية- جامعة عين شمس 37 () العدد الواحد والأربعون (الجزء الثاني) 2017 


\section{Acquisition of the nongeneric use of the definite article "the" by Egyptian EFL learners}

studies where cultural use was found to be the most difficult followed in order by textual use, structural use, and situational use.

The finding that cultural use of the was the easiest for the participants in this study contradicts the results of other studies such as Liu and Gleason (2002), Ansarin (2004), Chan (2005), Wong and Quek (2007), García Mayo (2008), and Dikilitas and Altay (2011). In these studies, cultural use was found to be the most difficult for the students. However, Liu and Gleason $(2002$, p. 8) point out that this use of the is not framed by the situation but is determined by conventional practice. For example, the is used with some disease names, but not all, and it is used before some geographical names, but not others. In addition, cultural use of the was excluded from some other previous studies such as Master (1987), Tarone and Parrish (1988), and Trademan (2002). According to Master (1987, p. 42), cultural use was excluded from the study as it was found that "there seemed to be no clear pattern of acquisition...[and that] a subject's knowledge and usage of the somewhat idiosyncratic rules for articles with proper nouns tended to depend on his or her experience in the world."

The present researcher believes that this contradiction could be attributed to differences in the type of test items used to examine students' use of this type in different studies. The fact that the test items targeting cultural use in the present study were direct and did not include any exceptions to the rules governing its use is the most probable reason for this finding.

Concerning the situation use of the, this study showed that it was the second easiest for the participants. However, in light of the previous discussion, the present researcher believes that it would have proved to be the easiest, had the

مجلة كلية التربية- جامعة عين شمس 38 () العدد الواحد والأربعون (الجزء الثاني) 2017 
items targeting cultural use in the Article Test been not so simple. Theoretically, situation use is an easier concept to understand compared to the cultural use of the. While the rules governing cultural use are complex and numerous and often shaped by conventional practice, situation use requires analysis of relatively straightforward grammatical rules. According to Liu and Gleason (2002), this use requires the referent associated with the noun to be perceived directly or indirectly by the interlocutors or to be known to members of a local community.

The finding that both textual and structural uses of the were the most difficult for the participants in this study is in line with that of Alenizi's (2013) study that replicated Liu and Gleason's study on Saudi EFL university learners. On the other hand, it is different from the findings of Liu and Gleason's (2002) study as well as studies that replicated their study including Ansarin (2004), Wong and Quek (2007) and Dikilitas and Altay (2011), where textual and structural uses ranked second and third in difficulty. Moreover, it contradicts the findings of Chan's (2005) study where textual use was found to be the easiest. Chan (2005, p. 46) argues that textual use is an easy concept to understand as it follows a rather simple rule - that is, after a noun has been mentioned once, it becomes known to the interlocutors involved. Therefore, when it is referred to again, the definite article is required.

With regard to the textual use of the, the present researcher believes that it is rather complex because it requires the analysis of textual information in order to identify the information that necessitates the use of the with the noun in question. That is, the previously mentioned noun must be identified and kept in mind in order to determine if the is needed when it is referred to again. Thus, the participants' difficulty with textual use can be attributed to the nature of the items targeting textual use in the Article Test. These

مجلة كلية التربية- جامعة عين شمس 39 () العدد الواحد والأربعون (الجزء الثاني) 2017 


\section{Acquisition of the nongeneric use of the definite article "the" by Egyptian EFL learners}

items were of the associative, not the direct, anaphoric type. In these contexts, the noun in question is associated with the previously mentioned noun, rather than being the same previously mentioned one (e.g., I got into the car, but the engine wouldn't start). In such cases, in addition to identifying and remembering the previously mentioned noun, the learner has to determine its relationship to the noun associated with it. This lack of direct previous reference might have caused more difficulty for the participants in this study. This interpretation is supported by Poesio and Vieira's (1998) study in which the participants were required to classify and locate direct anaphoric and associative anaphoric uses. Findings of their study showed that the participants performed much worse in identifying the associative anaphoric use than the direct one.

Similarly, the structural use of the is not simple as it requires the analysis of structural information to identify the noun, its modifier, and their relationship. However, the present researcher believes that the participants' difficulty with this use stems from the fact that not all nouns with an explanatory modifier require the use of the. For instance, in the sentence Yesterday, I met a girl who graduated from college this spring the definite article cannot be used before the noun girl because the noun phrase is a general reference. In other words, they were unable to determine whether the noun phrase is a general reference or not.

\section{B. Effect of students' English proficiency level}

At the time of the first administration of the test, the results of the ANOVA analysis reported in Table 6 show that the effect of the level of proficiency was statistically significant, with an $\mathrm{F}$ ratio of $F(1,232)=61.77, p<.001$ and

مجلة كلية التربية- جامعة عين شمس 40 () العدد الواحد والأربعون (الجزء الثاني) 2017 
an effect size (partial $\eta^{2}$ ) of .21. This result implies that $21 \%$ of the variance in the dependent variable was accounted for by the participants' proficiency level.

Table 10

Results of Independent Samples t-Tests on the Two Groups' Mean Scores on the First Administration of the Test

\begin{tabular}{|c|c|c|c|c|c|c|c|c|}
\hline \multirow[b]{2}{*}{$\begin{array}{l}\text { Type of } \\
\text { Use }\end{array}$} & \multirow[b]{2}{*}{ Group } & \multirow[b]{2}{*}{$M$} & \multirow[b]{2}{*}{$S D$} & \multicolumn{5}{|c|}{ t-test for Equality of Means } \\
\hline & & & & $t$ & $d f$ & $\begin{array}{c}M \\
\text { Difference }\end{array}$ & $\begin{array}{l}\text { Std. } \\
E D\end{array}$ & $p$ \\
\hline Textual & $\begin{array}{l}\operatorname{High}^{\mathrm{a}} \\
\text { Low }^{\mathrm{a}}\end{array}$ & $\begin{array}{l}82.50 \\
66.67\end{array}$ & $\begin{array}{l}18.74 \\
17.78\end{array}$ & 3.357 & 58 & 15.83 & 4.716 & .001 \\
\hline Structural & $\begin{array}{l}\text { High } \\
\text { Low }\end{array}$ & $\begin{array}{l}87.50 \\
61.25\end{array}$ & $\begin{array}{l}12.28 \\
19.52\end{array}$ & 6.235 & 58 & 26.25 & 4.21 & .001 \\
\hline Situation & $\begin{array}{l}\text { High } \\
\text { Low }\end{array}$ & $\begin{array}{l}89.16 \\
75.63\end{array}$ & $\begin{array}{l}12.60 \\
16.90\end{array}$ & 3.516 & 58 & 13.53 & 3.85 & .001 \\
\hline Cultural & $\begin{array}{l}\text { High } \\
\text { Low }\end{array}$ & $\begin{array}{l}97.33 \\
87.33\end{array}$ & $\begin{array}{l}6.91 \\
19.99\end{array}$ & 2.590 & 58 & 10.00 & 3.86 & .012 \\
\hline
\end{tabular}

${ }^{\mathrm{a}} \mathrm{n}=30$

To determine where the significant differences between the two groups across the four types of use lay, four independent samples t-tests were conducted. As shown in Table 10, the mean scores of the high-level group in all four types of use (textual, 82.50; structural, 87.50; situation, 89.16; cultural, 97.33) were higher than the mean scores of the low-level group (textual, 66.67; structural, 61.25; situation, 75.63; cultural). Results of the t-tests indicate that the mean score of the high-level group in each type of use was significantly higher than that of the low-level group.

These results reveal a significant improvement in the students' command of the four nongeneric uses of the as the level of proficiency increases. This finding concurs with the results of other studies such as Butler (2002), Liu and Gleason (2002), Ansarin (2004), Chan (2005), Wong and Quek (2007), García Mayo (2008), Dikilitas and Altay (2011), and Alenizi (2013). In his study of the acquisition of

مجلة كلية التربية- جامعة عين شمس 41 () العدد الواحد والأربعون (الجزء الثاني) 2017 


\section{Acquisition of the nongeneric use of the definite article "the" by Egyptian EFL learners}

the English article system by Japanese students with varying levels of proficiency, Butler (2002) concluded that the higher the students' levels of proficiency were, the more target-like usage they could achieve. Liu and Gleason (2002) found that the number of missed uses of the, in all four types, decreased as the subjects' proficiency increased, with the most significant decrease occurring at the intermediate level. The most significant improvements were in the structural and textual use of the, continuing through the advanced level On the other hand, the improvements in both situation and cultural uses were more slowly after the intermediate level. Ansarin's (2003) study revealed significant differences between the different proficiency levels. Both structural and situational uses improved in direct relation to the proficiency level, whereas textual and cultural uses were learned gradually and with varying difficulty. The results of García Mayo's (2008) study showed that learners underuse of obligatory the decreased significantly from elementary to low-intermediate level; however, this did not hold for the transition between the low intermediate and advanced levels. Alenizi (2013) concluded that there were developmental trends in the acquisition of the nongeneric uses of the related to proficiency as found that the advanced group showed a significantly higher accuracy of use in each of the four uses.

Similarly, the results of the ANOVA analysis conducted on the participants' scores on the second administration of the test reveal, as can be seen in Table 8 , that level of proficiency had a statistically significant effect, $F(1,232)=$ 4.39, $p<.05$, partial $\eta^{2}=.02$. This result implies that the participants' proficiency level accounted for only $2 \%$ of the variance in the dependent variable.

مجلة كلية التربية- جامعة عين شمس 42 () العدد الواحد والأربعون (الجزء الثانى) 2017 
To find out where the significant differences between the two groups across the four types of use lay, four independent samples t-tests were conducted. The results presented in Table 11 indicate that, unlike the results gained from the participants' performance on the first administration of the test, the only significant difference was in cultural use.

Careful examination of the mean scores of the two groups on the first and second administrations of the test helps to clarify this result. For textual use, while the mean score of the low-level group increased

Table 11

Results of Independent Samples t-Tests on the Two Groups' Mean Scores on the Second Administration of the Test

\begin{tabular}{|c|c|c|c|c|c|c|c|c|}
\hline \multirow[b]{2}{*}{$\begin{array}{l}\text { Type of } \\
\text { Use }\end{array}$} & \multirow{2}{*}{ Group } & \multirow{2}{*}{$M$} & \multirow{2}{*}{$S D$} & \multicolumn{5}{|c|}{ t-test for Equality of Means } \\
\hline & & & & $t$ & $d f$ & $\begin{array}{c}M \\
\text { Difference }\end{array}$ & $\begin{array}{l}S t d . \\
E D\end{array}$ & $p$ \\
\hline Textual & $\begin{array}{l}\text {High }^{\mathrm{a}} \\
\text { Low }^{\mathrm{a}}\end{array}$ & $\begin{array}{l}84.16 \\
78.33\end{array}$ & $\begin{array}{l}13.90 \\
15.72\end{array}$ & 1.523 & 58 & 5.83 & 3.83 & .133 \\
\hline Structural & $\begin{array}{l}\text { High } \\
\text { Low }\end{array}$ & $\begin{array}{l}82.50 \\
79.58\end{array}$ & $\begin{array}{l}11.18 \\
15.22\end{array}$ & .846 & 58 & 2.92 & 3.45 & .401 \\
\hline Situation & $\begin{array}{l}\text { High } \\
\text { Low }\end{array}$ & $\begin{array}{l}85.83 \\
84.83\end{array}$ & $\begin{array}{c}9.70 \\
10.72\end{array}$ & .379 & 58 & 1.00 & 2.64 & .706 \\
\hline Cultural & $\begin{array}{l}\text { High } \\
\text { Low }\end{array}$ & $\begin{array}{c}100.00 \\
97.33 \\
\end{array}$ & $\begin{array}{l}.00 \\
6.91\end{array}$ & 2.112 & 58 & 2.67 & 1.26 & .043 \\
\hline
\end{tabular}

${ }^{\mathrm{a}} \mathrm{n}=30$

by $11.66 \%$ (from 66.67 on the first to 78.33 on the second administration of the test), the mean score of the high-level group increased by only $1.66 \%$ (from 82.50 on the first to 84.16 on the second). With regard to structural use, the mean score of the low-level group increased $18.33 \%$ (from 61.25 to 79.58 ); in contrast, the mean score of the high-level group decreased by $5 \%$ (from 87.50 to 82.50 ). Concerning situation use, while the mean score of the low-level group increased by $9.2 \%$ (from 75.63 to 84.83 ), the mean score of the high-level group decreased by $3.33 \%$ (from 89.16 to 85.83 ).

مجلة كلية التربية- جامعة عين شمس 43 () العدد الواحد والأربعون (الجزء الثاني) 2017 


\section{Acquisition of the nongeneric use of the definite article "the" by Egyptian EFL learners}

To sum up, this result indicates that the participants in the low-level group noticeably improved their level of command of the textual, structural, and situation uses of the during the eight-month period separating the first and second administrations of the Article Test. In the meantime, the participants in the high-level group failed to improve their level of command of these uses. This result also shows that EFL students cease to develop their command of the nongeneric uses of the after reaching a certain level of command of these uses. It also gives support to the viewpoint that most nonnative speakers of English do not completely master the article system until a rather late stage during the course of language acquisition and, as Garcia Mayo (2008, p. 551) states, sometimes never reach native-like levels of proficiency.

\section{Conclusion}

The present study aimed to investigate Egyptian EFL university students' acquisition of the nongeneric use of the definite article the. Specifically, the study sought to find out whether the four nongeneric uses of the, proposed by Liu and Gleason (2002), present different levels of difficulty for the students; that is, whether these uses are acquired in a certain sequence. In addition, the study aimed to determine the extent to which students' English proficiency level (low, high) affected their acquisition of these nongeneric uses of the.

It can be concluded that the four nongeneric uses of the do not present equal levels of difficulty for Egyptian EFL university students and do not appear to be acquired at the same time. Regardless of the proficiency level of the students, the results obtained from both the first and second administrations of the Article Test reveal a hierarchy of

مجلة كلية التربية- جامعة عين شمس 44 () العدد الواحد والأربعون (الجزء الثاني) 2017 
difficulty among the four nongeneric uses of the, with both structural and textual uses being the most difficult followed in order by situation use and cultural use. However, the finding that cultural use of the proved to be the easiest for the participants in this study should be interpreted with caution as it contradicts the findings from other studies where cultural use was found to be the most difficult. A possible reason for this contradiction may be the limited number of items targeting cultural use in the Article Test; however, further research may yield findings that can explain this contradiction.

With regard to the effect of level of proficiency, the results obtained from the first administration of the test reveal a significant improvement in the students' command of each of the four nongeneric uses of the as the level of proficiency increases. However, on the second administration of the test, the results reveal a significant improvement in cultural use only. This suggests that, despite the difference in the language proficiency level, the learners have the same difficulty level with the textual, structural, and situational uses. In addition, this implies that these uses are learned gradually and with difficulty. Thus, they should be introduced gradually over a long period, with recycling.

Importantly, unlike many previous studies on L2 article use and acquisition, the present study investigated EFL leaners' acquisition of the nongeneric use of the over a period of eight months. The results indicate that while the participants in the low-level group noticeably improved their level of command of the textual, structural, and situation uses of the during the eight-month period separating the first and second administrations of the test, the participants in the high-level group failed to do so. This implies that formal classroom training during this period has been successful in helping the learners in the low-level group to recognize the places where the nongeneric use of the is required.

مجلة كلية التربية- جامعة عين شمس 45 () العدد الواحد والأربعون (الجزء الثاني) 2017 


\section{Acquisition of the nongeneric use of the definite article "the" by Egyptian EFL learners}

According to Master (1994, p. 247), classroom instruction serves as "a means of accelerating that acquisition by making students aware of and increasing their conscious control of the way the article system works."

\section{Implications}

It is hoped that the present study provides instructors and material developers with a better understanding of Egyptian EFL university students' acquisition of the nongeneric use of the definite article the. This, in turn, may lead to more effective teaching activities that take into consideration students' acquisition sequence. The results pedagogically suggest that the nongeneric uses of the definite article the are difficult to acquire; they are learned gradually and with difficulty. Thus, instructors should not expect the learners to grasp these uses at the same time. They should be introduced gradually over a long period and with recycling.

With regard to the teaching of nongeneric uses of the, the finding that both structural and textual uses were the most difficult suggests that learners need to get adequate practice in these uses. Such practice can be provided in conjunction with the teaching of reading and writing skills. With regard to textual use, it is suggested that reading instructors expose learners to both direct anaphoric and associative anaphoric uses and give them practice in identifying and locating the referent associated with the noun. As for structural use, the practice should concentrate on helping learners to identify both preand post-modifiers. Writing instructors can also help the learners with the different nongeneric uses of the, especially as an editing skill, as well as by encouraging them to keep a tally of their errors. Concerning situation use, Liu and Gleason (2002) suggest that instructors should start with teaching this nongeneric use of the, making use of the objects readily

مجلة كلية التربية- جامعة عين شمس 46 () العدد الواحد والأربعون (الجزء الثان) 2017 
available in class, since it requires "a more kinesthetic, auditory, tactile, and visual learning, rather than the kind of cognitive learning associated with the structural and textual uses" (p. 19) . Furthermore, this conforms to a languageteaching principle that both the Natural Approach (Krashen \& Terrell, 1983) and the TPR approach (Asher, 1982) follow closely; that is, to begin with things that students can see, touch, and hear. Finally, since the rules governing the cultural uses of the are numerous, complex, and are often conventional and cannot be deduced from general rules of article use, the learning of these uses requires greater effort from both instructors and learners. Thus, instructors need to proceed gradually in teaching these uses, be aware of the interlanguage differences in these uses in Arabic and in English, and illustrate them to their learners who must memorize these different uses on a case-by-case basis.

\section{Research Limitations}

The present study aims to provide a clearer picture of Egyptian EFL learners' acquisition of the nongeneric use of the. However, it is limited because the number of test items targeting each of the four nongeneric uses of the in the Article Test is not large enough. In particular, the items targeting the cultural use of the do not cover the different categories of this use.

\section{Further Research}

To conduct similar research in the future, it would be of interest to have a test that involves a greater variety of data, including data from learner-produced language. Furthermore, both quantitative and qualitative data analyses, including posttest interviews, should be conducted to get a better understanding of the reasons behind learners' choices on selected test items.

مجلة كلية التربية- جامعة عين شمس 47 () العدد الواحد والأربعون (الجزء الثانى) 2017 
Acquisition of the nongeneric use of the definite article "the" by Egyptian EFL learners

\section{References}

Asher, J. (1982). Learning another language through action: The complete teacher's guide book ( $2^{\text {nd }}$ ed.). Los Gatos, CA: Sky Oaks Production.

Alenizi, A. M. (2013). The acquisition of nongeneric uses of the English definite article "the" by Arabic speakers of English (Unpublished master's thesis). Southern Illinois University, Carbondale.

Ansarin, A. (2004). Nongeneric use of the definite article 'the' by Persian learners. Journal of Faculty of Letters and Humanities, 47, 1-11.

Bickerton, D. (1981). Roots of Language. Ann Arbor, MI: Karoma.

Butler, Y.G. (2002). Second language learners' theories on the use of English articles: an analysis of the metalinguistic knowledge use by Japanese students in acquiring the English article system. Studies in Second Language Acquisition. 24(3), 451-480. doi:10.1017/ s0272263102003042

Celce-Murcia, M., \& Larsen-Freeman, D. (1999). The grammar book: an ESL teacher's course (2nd ed). Boston: Heinle \& Heinle.

Chan, W. (2005). The acquisition of the English article system by Hong Kong students (Unpublished master's thesis). The Chinese University of Hong Kong, Hong Kong.

Dikilitas, K. \& Altay, M. (2011). Acquisition sequence of four categories of non-generic use of the English definite article the by Turkish speakers. Research on Youth and Language, 5(2), 183-198.

Garcia Mayo, M.P. (2008). The acquisition of four nongeneric uses of the article the by Spanish EFL learners. System, 36(4), 550-565. doi:10.1016/j.system.2008.08.001

مجلة كلية التربية- جامعة عين شمس 48 () العدد الواحد والأربعون (الجزء الثاني) 2017 
Hawkins, J. A. (1978). Definiteness and indefiniteness. San Diego, CA: Academic Press.

Huebner, T. (1983). A longitudinal analysis of the acquisition of English. Ann Arbor, MI: Karoma.

Huebner, T. (1985). System and variability in inter-language syntax. Language Learning 35(2), 141-63.

doi:10.1111/j.1467-1770.1985. tb01022.x

Krashen, S., \& Terrell, T. (1983). The natural approach: Language acquisition in the classroom. Oxford: Pergamon.

Liu, D. \& Gleason, J. L. (2002). Acquisition of the article the by nonnative speakers of English. An analysis of four nongeneric uses. Studies in Second Language Acquisition, 24(1), 1-26. doi:10.1017/ s0272263102001018

Master, P., 1987. A cross-linguistic interlanguage analysis of the acquisition of the English article system (Unpublished doctoral dissertation). University of California, Los Angeles.

Master, P. (1990). Teaching the English articles as a binary system. TESOL Quarterly, 24(3), 461-498. doi: $10.2307 / 3587230$

Master, P.(1994). The effect of systematic instruction on learning the English article system. In T. Odlin (Ed.), Perspectives on Pedagogical Grammar. Cambridge University Press, Cambridge, pp. 229-252.

Master, P. (2002). Information structure and article pedagogy. System 30(3), 33 1-348. doi: 10.1016/s0346$251 \mathrm{x}(02) 00018-0$

McEnery, T., Xiao, R., \& Tono, Y. (2006). Corpus-based language studies: an advanced resource book. London: Routledge.

Mizuno, M. (1999). Inter-language analysis of the English article system: Some cognitive constraints facing the

مجلة كلية التربية- جامعة عين شمس 49 () العدد الواحد والأربعون (الجزء الثان) 2017 
Acquisition of the nongeneric use of the definite article "the" by Egyptian EFL learners

Japanese adult learners. International Review of Applied Linguistics in Language Teaching, 37, 127-153.

Parrish, B. (1987). A new look at methodologies in the study of article acquisition for learners of ESL. Language Learning, 37 (3), 361-384. doi:10.1111/j.14671770.1987.tb00576.x

Poesio, M., \& Vieira, R. (1998). A corpus-based investigation of definite description use. Computational Linguistics, 24, 183-216.

Quirk, R., Greenbaum, S., Leech, G., \& Svartvik, J. (1985). A comprehensive grammar of the English language. London: Longman.

Robertson, D. (2000). Variability in the use of the English article system by Chinese learners of English. Second language Research, $16(2)$,

135-172. doi:10.1191/026765800672262975

Takahashi, T. (1997). Japanese Learners' Acquisition and Use of the English Article System. Edinburgh Working Papers in Applied Linguistics, 8, 98-110.

Tarone, E., \& Parrish, B. (1988). Task-related variation in interlanguage: The case of articles. Language Learning, 38(1), 21-44. doi:10.1111/j.1467-1770.1988.tb00400.x

Trademan, J. E. (2002). The acquisition of the English article system by native speakers of Spanish and Japanese: a cross-linguistic comparison (Unpublished doctoral dissertation). The University of New Mexico, Albuquerque, New Mexico.

Wong, B. E.\& Quek, S. T. (2007). Acquisition of the English definite article by Chinese and Malay ESL learners. Electronic Journal of Foreign Language Teaching, 4(2) 210-234

مجلة كلية التربية- جامعة عين شمس 50 () العدد الواحد والأربعون (الجزء الثانى) 2017 


\section{APPENDIX "A"}

\section{Article Test}

1) Excuse me, would you pass me (a / the / $\varnothing$ ) salt, please?

2) (A / The / $\emptyset$ ) beef that is produced in the United Kingdom is not allowed to be exported to other European nations.

3 ) It was Friday; so there was (a / the / $\emptyset$ ) large crowd in the zoo.

4) Japan is a country in Asia. (A / The / Ø) capital is Tokyo.

5) A: Let's go to $(a /$ the $/ \varnothing)$ restaurant this evening.

B: That's a good idea. Which restaurant shall we go to?

6) That's interesting. Actually, this is (a / the / Ø) funniest story I have ever heard.

7) The biggest problem in the world today is (an / the / Ø) air pollution.

8) Yesterday, I met (a / the / Ø) girl who graduated from college this spring.

9) As soon as I got into the lift, I asked the operator to push (a / the / $\varnothing$ ) button for the $6^{\text {th }}$ floor.

10) I asked him to go with me. But (a / the / $\emptyset$ ) first word he said was "No."

11) John hasn't got (a / the / Ø) job at the moment.

12) A: We're going to $(\mathrm{a} /$ the / Ø) town center? Do you want to come with us?

B: Sure.

13) I have just seen (a / the / Ø) play that I can highly recommend to anyone.

14) I looked for (a / the / $\emptyset$ ) place where Mr. Sakamoto was born, but I couldn't find it.

15) A: Any news about the brutal murder in the newspaper?

B: Well, it says that (a / the / $\varnothing$ ) middle-aged man was arrested this morning.

16) Be careful: there is (a / the / $\emptyset$ ) glass everywhere.

17) My room is on (a / the / Ø) third floor.

18) I have taken part in many competitions but never won (a / the / $\emptyset$ ) first prize.

مجلة كلية التربية- جامعة عين شمس 51 () العدد الواحد والأربعون (الجزء الثان) 2017 
19) A: Did you enjoy the lecture?

B: Most of it, but I didn't like (a / the / $\varnothing$ ) jokes.

20) A: How was (a / the / Ø) winter vacation, John?

B: It was really good. I went to Hawaii.

21) (A / The / $\emptyset$ ) beginning of the movie was boring.

22) Yesterday, Tom saw (an / the / $\varnothing$ ) advertisement for a new drink. Then he went to the shop and bought a bottle of the new drink.

23) Most of European nations are against (a / the / Ø) whale fishing.

24) Be careful! (An / The / Ø) oven is still hot.

25) Jane is (an / the / $\emptyset$ ) only person I know at the party.

26) When we were in Japan, we stayed at (a / the / Ø) small hotel in Tokyo.

27) Freezing is (a /the / $\emptyset$ ) way of preserving food.

28) I had a pleasant time at the party yesterday. (A / The / Ø) wine was really good.

29) A: Did you see (a / the / Ø) baseball game yesterday?

B: No. I didn't have time to see it.

30) A: I often forget (a / the / Ø) names of my students recently.

B: You are getting old.

31) Look at (a / the / $\varnothing$ ) sharks. They look very hungry.

32) A: Do you like to live in (a / the / Ø) city like this?

B: No, not really. I prefer to stay in the country.

33) She was very kind. She gave me (a / the / $\varnothing$ ) best advice I could get as to the purchase of a house.

34) We have (a / the / $\emptyset$ ) reliable information that a terrorist attack is planned next mouth.

35) A: Could you tell me the way to (a / the / $\varnothing$ ) city hall?

B: Sure. Go along this street for three blocks and....

36) A: Have you got (a/ the $/ \varnothing$ ) record which you promised to lend me the other day?

مجلة كلية التربية- جامعة عين شمس 52 () العدد الواحد والأربعون (الجزء الثاني) رسم 2017 
B: I am sorry. I forgot to bring it.

37) A: Stop at the corner. (A / The / Ø) car might come.

B: I don't see any cars, Mom.

38) A: I saw (a / the / Ø) totally strange man near Kate's house.

B: How scary.

39) I got into the car, but (an / the / Ø) engine wouldn't start.

40) A: What do you think of him?

B: Honestly speaking, I think he is (a / the / Ø) secondclass player.

41) When the phone rang, father was reading (a / the / Ø) new book he got for his birthday.

42) I borrowed (a / the / $\emptyset$ ) book of $16^{\text {th }}$ century British history.

43) Many tourists are surprised to know that (a / the / Ø) houses are very expensive in Japan.

44) A: Why were you late for school today?

B: Because (a / the / $\varnothing$ ) bus was late.

45) Have a good vacation. Don't forget to send me (a / the / $\varnothing)$ postcard.

46) I am studying (a / the / Ø) development of English agriculture. 
Acquisition of the nongeneric use of the definite article "the" by Egyptian EFL learners 